\title{
Haematological Changes of Half-Marathon Runners in the Sub-Saharan African Environment
}

\section{Jean Georges André Moulongo ${ }^{1 *}$, Elvina Lys Surêche Massamba ${ }^{2}$, Jean Martin Moussoki ${ }^{1}$, Mathias Cyriaque Ndalla ${ }^{3}$, Didier Pambou Moussitou ${ }^{1}$, Jacques N'gbandzo On'esala ${ }^{4}$, Christophe Pela Lola4, Bernard Packa Tchissambou' ${ }^{1}$, Alphonse Massamba ${ }^{1}$}

\author{
${ }^{1}$ Laboratory of Sport Biosciences, Higher Institute of Physical and Sport Education, Marien NGOUABI University, Brazzaville, \\ Congo \\ ${ }^{2}$ Laboratory Health and Adapted Physical Activities, Higher Institute of Physical and Sport Education, Marien NGOUABI \\ University, Brazzaville, Congo \\ ${ }^{3}$ Biomedical Analyses Center, Makelekele, Brazzaville, Congo \\ ${ }^{4}$ Department of Human Motricity Sciences, Faculty of Sciences, National Teaching University, Kinshasa, Congo \\ Email: *jgamoulongo@gmail.com
}

How to cite this paper: Moulongo, J.G.A., Massamba, E.L.S., Moussoki, J.M., Ndalla, M.C., Pambou Moussitou, D., N'gbandzo On'esala, J., Pela Lola, C., Packa Tchissambou, B. and Massamba, A. (2019) Haematological Changes of Half-Marathon Runners in the Sub-Saharan African Environment. Journal of Biosciences and Medicines, 7, 96-110.

https://doi.org/10.4236/jbm.2019.79009

Received: August 1, 2019

Accepted: September 15, 2019

Published: September 18, 2019

Copyright @ 2019 by author(s) and Scientific Research Publishing Inc. This work is licensed under the Creative Commons Attribution International License (CC BY 4.0).

http://creativecommons.org/licenses/by/4.0/ c) (i) Open Access

\begin{abstract}
Background: Measurement of haematological parameters has been historically helpful in the diagnosis of many diseases in endurance sportsmen. The modifications of these parameters during endurance race have not yet been evaluated in many African countries. Objectives: To determine haematological values before and immediately after a half-marathon event, as well as within 24 hours after the race and to analyze the changes observed. Methods: A cross-sectional study was conducted from 10 to 21 August 2018 at Brazzaville, Congo. All measurements were confined to 76 male participants (39 specialists vs 37 no specialists of endurance race) in the Brazzaville half-marathon $(21.1 \mathrm{~km}$ ), aged between 19 - 39 years (mean age: $26.7 \pm 2.6$ years). Coulter profiles with differential white cell counts and haptoglobin levels were determined in venous sample before and after competitive half-marathon race. The same measurements were performed during the 24 hrs following the competition. Results: In the pre-race sample, mild anemia was detected in 12 subjects and mild thrombocytopenia in 7 subjects. Haptoglobin levels were reduced in 5 subjects. Haematological values, all post-race, varied significantly before and after race, particularly for $\mathrm{RBC}, \mathrm{Hb}$, Hct, PLT, MCV, MCH, MCHC, WBC, neutrophil counts, lymphocyte counts, monocyte counts, basophil counts, eosinophil counts and haptoglobin. These differences between specialists and no specialists were statistically $(\mathrm{p}<0.05)$. During $24 \mathrm{~h}$ after race, the major changes involved a progressive and signifi-
\end{abstract}


cant increase in $\mathrm{MCH}$ and $\mathrm{MCHC}$, but a decrease in $\mathrm{Hb}, \mathrm{Hct}, \mathrm{WBC}$ and leukocyte values. Conclusion: Our data may help sport physicians, sport physiologists and trainers to better follow-up haematological reactions associated with the half-marathon race.

\section{Keywords}

Haematology, Half-Marathon Running, Haptoglobin, African Black, Congo

\section{Introduction}

The half-marathon is the most commonly used term for the $21.1 \mathrm{~km}$ running sport event. The rule remains the same for the different athletics federations that govern the discipline around the world. This is a test that results in significant physical stress [1], however, lower than that noted in the marathon event [2] and the ultra-endurance races [3]. Long practiced in Europe and America, the half-marathon has appeared in sub-Saharan black Africa only during the last thirty years unlike East Africa where this practice is older. In the Congo, a country in Central Africa, the Brazzaville Half Marathon dates back to 2003 and has been organized every year since then by the Congolese Athletics Federation on the occasion of the national holiday of August 15th. Since its establishment in the Congo until today, there has been a steady and clear increase in the number of participants in this competition, reaching a total of 4253 (702 women against 3551 men) in the Congo and other countries in Africa and Western Europe in 2018 [4]. During this year, the Brazzaville Half Marathon celebrated its fifteenth edition. However, while the physiological adaptations of the body during marathon and ultra-endurance events are well documented [5] [6] [7] [8] [9], this is not the case for half marathon race. In sub-Saharan black Africa, particularly in the Congo, no study has been conducted on the immediate physiological effects of the half-marathon on haematological changes involving peripheral blood components and 24 hours after the competition. However, these can be related not only to the subjects and the form of the race, but also to the climatic conditions and the topography of the road. This justifies the present study, considering the current practice of the half-marathon by the amateur subjects no specialists of the discipline. The objectives are to determine the hematological values before and after the race, and during and 24 hours after the competition and to evaluate its impact on the biochemical, haemorheological and plasma peripheral blood responses.

\section{Materials and Methods}

\subsection{Participants}

A cross-sectional and experimental study was conducted in Brazzaville, capital of the Republic of Congo, from 10 to 21 August 2018. A total of 76 men, all 
amateurs, participated in the study: 39 amateur runners, not affiliated to the Congolese Athletics Federation; 37 amateur runners, specialists in endurance race at sports clubs affiliated to the Congolese Athletics Federation. They were selected among the 3105 regular participants in the half marathon event on $\mathrm{Au}$ gust 14, 2018; the selection process was the probabilistic method and the technique of two random draws with two fractions of $1 / 5$, that is to say 124 subjects. At the end of this process, 124 subjects were selected. Those were to obey criteria for inclusion following: Congolese of ethnic origin and ethnicity; reside on Congolese territory for at least one year (specific dietary habits); be unharmed one month before diseases (pulmonary infections, arterial hypertension, diabetes, malaria, viral hepatitis); a hemoglobin level more than $11.5 \mathrm{~g} / \mathrm{dL}$; have participated in at least one Brazzaville Half Marathon competition in the last five years; be 18 years of age and under 40 years of age; informed and written consent to participate in the study. Since the number of women in the top 100 ranks was small $(n=9)$, they were excluded from the sample. The abandonment of the race during the competition was also an exclusion criterion. Into definitive, all the 76 participants filled the criteria of selection referred to above. The experimental protocol was accepted by the National Committee of Ethics for Research in Health Sciences of the Congolese Ministry of Scientific and Technical Research.

\subsection{Material}

An individual information sheet was used to collect information from each subject on age, history of pathology, number of years of endurance training and weekly frequency of training sessions of running practice (see appendix).

Anthropometric measurements were performed, including determination of body mass using a digital beam balance (Seca; accuracy, $0.13 \mathrm{~kg}$ by default) and height measurement using a wall scale; then the body mass index (BMI) was calculated.

Tubes containing EDTA $(1.5 \mathrm{mg} / \mathrm{ml}$ as anticoagulant) collected $10 \mathrm{ml}$ of venous blood. Twelve peripheral blood parameters were subsequently determined using a Coulter counter analyzer (Coulter AcT diff, Beckman Coulter, Miami, FL, USA). Hemoglobin ( $\mathrm{Hb}$ ) concentration was determined by HemoCue Hb 201 + (USA/Canada, Friwo, Mod nR FE15 1060 D035). Total leukocyte counts were determined by haemocymeter methods. Serum haptoglobin (Hp) was measured by radial immunodiffusion (Behring Diagnostics, Marburg, Germany). A blood smear was performed for manual white blood cell, differentiation and determination of percentages and absolute values of lymphocytes, neutrophils, eosinophils, basophils and monocytes for each subject. All hematological analyses were performed at the Hematology Laboratory of the Pasteur Institute of Brazzaville. The storage of blood samples at room temperature lasted four hours (first samples) or two hours (second samples). 


\subsection{Experimental Procedure}

On the event of competition, all racers of Congolese nationality and black ethnicity filled in the individual information sheets and the informed consent cards. Then, pre-screening tests included a physical examination and rapid haemoglobin. On the day of the race and three hours before, the first blood samples were taken. After the test the second samples were taken after arrival after 24 hours of recovery ( $3 \mathrm{~h}, 6 \mathrm{~h}$ and $24 \mathrm{~h})$.

All samples were taken at the cubital fold of the left elbow and the single-blind assays, i.e., the laboratory technician did not know the source of the blood sample he was analyzing. The manufacturers' instructions for the devices and reagents have been strictly adhered in order to reduce the error in measurement accuracy. At the end of the race and samples, subjects were allowed to drink plain or mineral water at their convenience.

The $21.1 \mathrm{~km}$ half-marathon race took place between 8:30 am and 12:00, along the avenues of Brazzaville. The elevations varied between $5 \%$ and $37 \%$ of slope. The climatic conditions indicated an ambient temperature of $28.5^{\circ} \mathrm{C}$ and a relative humidity of $90.3 \%$, as recorded in the morning for the city of Brazzaville, by the National Meteorological Department (ANAC) of the Congo.

\subsection{Variables}

Before and after the run of the half-marathon, the variables studied were: Red Blood Cells (RBC), hemoglobin ( $\mathrm{Hb})$, hematocrit (Hct), Mean Cell Volume $(\mathrm{MCV})$, Plasma Volume Variation $(\Delta \mathrm{VP})$, Mean Cell Volume (MCV), Mean Cell Hemoglobin (MCH), Mean Cell Hemoglobin Concentration (MCHC), Red Cell Distribution Width (RDW), White Blood Cell (WBC), neutrophil count, lymphocyte count, neutrophil count, monocyte count, eosinophil count, basophil count, platelet count (PLT), Mean Platelet Volume (MPV) and serum haptoglobin. The motor performances achieved (run times, in hours and minutes) by the riders were recorded. The variations of these parameters of interest were calculated, as well as that of the plasma volume variation (VP), between the rest and the end of the race determined using formula of Van Beaumont [10] following:

$$
\Delta V P(\%)=100 \times\left(H b_{1} / H b_{2}\right) \times\left\{\left[1-\left(H_{c t} / 100\right)\right] /\left[1-\left(H c t_{2} / 100\right)\right]\right\}-100
$$

In this equation, $H b 1$ and $H c t 1$ represent respectively the rates of $H b$ and hematocrite of rest, then $H b 2$ and $H c t 2$ those measured in race end of half-marathon.

\subsection{Statistical Analysis}

The recorded data were treated by software Statistica (Stat Soft Inc.), version 5.5. Descriptive statistics were used by calculation percentages, averages and standard deviations. The results are expressed in percent (\%) or average values (x) accompanied by standard deviation (SD). After having checked the normality of 
the distribution of the variable (Kolgomorov-Smirnov test's), the comparisons between two averages carried out using the Student's t test. In the event of non-normality, the significant character of the possible differences was judged starting from the nonparametric test of Freedman. For two percentages, it was judged by the Sokal's S test [11]. The relationship between two variables was analyzed by calculating the $\mathrm{r}$ correlation spearman coefficients. During the 24 hours following the competition, data were analyzed by two factors and one way Anova method, completed by post hoc Scheffe's test. Level of significance of all tests considered at $\mathrm{p}<0.05$.

\section{Results}

\subsection{Morphological Characteristics}

The mean anthropometrical data are shown in Table 1. One can notice on this table that the two groups (specialists in the endurance races vs no specialists) were comparable for age, size and weight. The subjects presented a normal stoutness, with an average BMI of $22.6 \pm 1.4 \mathrm{~kg} / \mathrm{m}^{2}$; however, the values of BMI at the specialists subjects of endurance race were statistically lower $(\mathrm{p}<0.01)$ than those of no specialists.

The performances carried out by the specialist runners were better than those of the no specialists: $121.1 \pm 10.5$ min against $137.5 \pm 11.4 \mathrm{~min}(\mathrm{p}<0.05)$.

\subsection{Haematological Data}

Of the 76 runners studied, 12 (15.8\%) were found to have a mild anemia $(\mathrm{Hb}<$ $14.0 \mathrm{~g} / \mathrm{dL}$ ). All essentially of normochromic, normocytic type as evaluated by $\mathrm{MCV}, \mathrm{MCH}$, and microscopic appearances. In 34 subjects (or $44.7 \%$ ), the $\mathrm{Hb}$ level was only slightly reduced (13 - $14 \mathrm{~g} / \mathrm{dL})$, whereas the remaining $30(28.5 \%)$ had $\mathrm{Hb}$ levels comprised with $\mathrm{Hb} \mathrm{Hb} 13.0 \mathrm{~g} / \mathrm{Dl}$. Microscopy of the peripheral blood film showed the characteristic morphological features of asplenism or hyposplenism.

The mean values $( \pm \mathrm{SD})$ and the statistical significance of the red cell, leukocyte, and platelet parameters along with the serum haptoglobin levels before and after the half marathon are presented in Table 2.

Table 1. Anthropometric profile and race time of runners.

\begin{tabular}{cccc}
\hline & $\begin{array}{c}\text { Whole group } \\
(\mathbf{n}=76)\end{array}$ & $\begin{array}{c}\text { Specialists } \\
(\mathbf{n}=\mathbf{3 7})\end{array}$ & $\begin{array}{c}\text { No specialists } \\
(\mathbf{n}=\mathbf{3 9})\end{array}$ \\
\hline Age $(\mathrm{yrs})$ & $26.7 \pm 2.9$ & $27.8 \pm 3.2$ & $25.7 \pm 2.6$ \\
Height $(\mathrm{cm})$ & $173.9 \pm 3.7$ & $174.6 \pm 3.4$ & $173.3 \pm 4.1$ \\
Body weight $(\mathrm{kg})$ & $68.5 \pm 2.8$ & $66.4 \pm 2.2$ & $68.7 \pm 3.5$ \\
BMI $\left(\mathrm{kg} / \mathrm{cm}^{2}\right)$ & $22.6 \pm 1.4$ & $21.8 \pm 0.5$ & $23.4 \pm 2.3$ \\
Race time $(\mathrm{min})$ & $129.3 \pm 10.9$ & $112.1 \pm 10.5$ & $137.5 \pm 11.4$ \\
\hline
\end{tabular}

BMI: Body mass index. 
Table 2. Mean values $( \pm \mathrm{SD})$ of red cells, leukocytes and platelets and platelet parameters and serum haptoglobin levels before and after race for whole sample.

\begin{tabular}{|c|c|c|c|}
\hline & $\begin{array}{c}\text { Before } \\
(n=76)\end{array}$ & $\begin{array}{c}\text { After } \\
(n=76)\end{array}$ & $\begin{array}{l}\text { Reference } \\
\text { values }\end{array}$ \\
\hline $\mathrm{RBC}\left(\times 10^{16} / \mu \mathrm{L}\right)$ & $4.8 \pm 0.2$ & $5.2 \pm 0.1^{\star *}$ & $4.5-5.50$ \\
\hline $\mathrm{Hb}(\mathrm{g} / \mathrm{dL})$ & $4.9 \pm 0.1$ & $15.2 \pm 0.1^{* *}$ & $13.0-16.2$ \\
\hline Hct (\%) & $43.2 \pm 3.0$ & $45.4 \pm 2.3^{\star}$ & $40.0-54.0$ \\
\hline $\operatorname{PLT}\left(\times 10^{13} / \mu \mathrm{L}\right)$ & $239 \pm 13$ & $351 \pm 26$ & $150-500$ \\
\hline$\Delta \mathrm{VP}(\%)$ & -- & $14.7 \pm 1.2$ & -- \\
\hline MCV (fL) & $89.2 \pm 16$ & $93.8 \pm 0.9^{* *}$ & $75-95$ \\
\hline $\mathrm{MCH}(\mathrm{pg})$ & $30.5 \pm 0.8$ & $29.6 \pm 0.5^{*}$ & $30-35$ \\
\hline $\mathrm{MCH}(\mathrm{g} / \mathrm{dL})$ & $31.7 \pm 0.5$ & $32.4 \pm 0.8^{*}$ & $30-35$ \\
\hline RDW (\%) & $12.8 \pm 0.6$ & $13.3 \pm 0.4^{\star}$ & $10-15$ \\
\hline $\mathrm{WBC}(/ \mu \mathrm{L})$ & $5413 \pm 104$ & $6742 \pm 131^{*}$ & $4000-10,000$ \\
\hline Neutr. $(/ \mu \mathrm{L})$ & $3740 \pm 95$ & $5263 \pm 123^{*}$ & $2500-7500$ \\
\hline Lymph. $(/ \mu \mathrm{L})$ & $2109 \pm 83$ & $2215 \pm 64^{*}$ & $1000-4000$ \\
\hline Mono. $(/ \mu \mathrm{L})$ & $589 \pm 62$ & $713 \pm 48^{*}$ & $400-1000$ \\
\hline Eosino. $(/ \mu \mathrm{L})$ & $176 \pm 15$ & $175 \pm 12^{*}$ & $40-500$ \\
\hline Baso. $(/ \mu \mathrm{L})$ & $49 \pm 12$ & $51 \pm 7^{\star}$ & $<500$ \\
\hline MPV (fL) & $8.3 \pm 0.4$ & $8.8 \pm 0.2^{*}$ & $6.5-11$ \\
\hline Haptoglobin $(\mathrm{g} / \mathrm{L})$ & $1.14 \pm 0.71$ & $0.96 \pm 0.21^{*}$ & -- \\
\hline
\end{tabular}

${ }^{* *}, \mathrm{p}<0.01 ;{ }^{*}, \mathrm{p}<0.05$.

Of the 76 male runners studied, 22 were found to have a mild anemia $(\mathrm{Hb}<$ $14.0 \mathrm{~g} / \mathrm{dl}$ ), all essentially of normochromic, normocytic type as evaluated by $\mathrm{MCV}, \mathrm{MCH}$, and microscopic appearances.

In 19 subjects, the $\mathrm{Hb}$ level was only slightly reduced $(13-14 \mathrm{~g} / \mathrm{dl})$, whereas the remaining 3 had significantly lower levels of $12.6,12.6$, and 12.5 , respectively. In one subject with $\mathrm{Hb} 13.0 \mu \mathrm{g} / \mathrm{dL}$, microscopy of the peripheral blood film showed the characteristic morphological features of asplenism or hyposplenism.

The most significant red cell change following the marathon was the increase in $\triangle \mathrm{MCV}(+14.7 \%)$ accompanied by a corresponding increase in red cell count $(+8.3 \%)$ and $\mathrm{Hb}$ level $(+2.0 \%)$. These changes indicate a post-race decrease in plasma volume of $6.5 \% \pm 8.8 \%(\mathrm{p}<0.0001)$. It should also be noted that in all three studies there is a significant increase in the immediate post-race MCV.

In the pre-race leukocyte counts, seven subjects (or 9.2\%) were found to have a marginal thrombocytopenia with respective events of $2300-2400 / \mu \mathrm{L}$ (3 cases) and $2100-2500 / \mu \mathrm{L}$ ( 4 cases). The striking change in the post-race sample was the dramatic increase ( 7 cases) in the total counts due almost exclusively to an increase in neutrophils but involving lymphocytes and monocytes also. It is of interest that the four runners with low initial counts had an even greater rise (fivefold) in their post-race samples. The runners with high initial counts had a 
neutrophil/lymphocyte ratio of $2.09 \pm 1.34$ and those with low counts a ratio of $1.42 \pm 0.65$. There was no correlation of time taken to complete the race, with either the post-race leukocyte count $(r=0.055)$ or the increment incurred during the race $(r=+0.008)$.

In the pre-race platelet measurements, nine subjects (or 13.2\%) were found to have a marginal thrombocytopenia $\left(<150 \times 10^{6} / \mu \mathrm{L}\right)$. the changes in platelet number following the half-marathon generally mirrored those of the leukocytes $(r=0.387)$, the being a substantial increase from the pre-race level. The pre-race platelet counts also correlated positively with the pre-race leukocyte counts $(\mathrm{r}=$ 0.426). The MPV did not change significantly after the race (Table 2 ).

In the pre-race $\mathrm{Hp}$ measurements, 5 runners (or 6.6\%) were found to have subnormal levels $(<0.3 \mathrm{~g} / \mathrm{l})$. In the post-race samples, there was a significant fall $(\mathrm{p}<0.01)$ in the mean Hp level on 72 runners. No correlation was established with race time, age, height, pre-race body weight, $\mathrm{Hb}$, and RBC or post- and post-race leukocyte counts. However, in the 5 runners with pre-race hypothaptoglobinemia there was a strong correlation with race time (mean 116 min; range $130-175 \mathrm{~min})$. In the post-race samples overall, $92 \%(\mathrm{n}=70)$ of subjects exhibited a fall in $\mathrm{Hp} 3.4 \%(\mathrm{n}=3)$ had no change, and 3 showed a slight rise.

With regard to the effects of endurance training on the hematological profile (Table 3), no significant difference was observed before the race between specialists and non-specialists at the level of training for. Platelet Counts, MCV, $\mathrm{MCH}, \mathrm{WBC}$, neutrophil Count, lymphocyte count and basophil count. Higher values $(\mathrm{p}<0.05)$ were noted among specialists at RBC $(\Delta=+9.0 \%), \mathrm{Hbc}(\Delta=$ $+10 \%)$, RDW $(\Delta=+4.6 \%)$, monocytes $(\Delta=+5.1 \%)$, eosinophils $(\Delta=+8.7 \%)$ and haptoglobin $(\Delta=+17.6 \%)$; they were found in no specialists for Hb, Hct, $\mathrm{MCHC}$ and MPV. Immediately after the race the non-significant differences remained for MCV, MCH, WBC, Neutrophil count and Lymphocyte count. However, the significantly higher values were noted in specialists runners. They concerned $\mathrm{Hb}(\Delta=+2.6 \%), \Delta \mathrm{PV}(\Delta=+2.6 \%)$, RDW $(\Delta=+5.3 \%)$, basophil counts $(\Delta=+24.0 \%)$, MPV $(\Delta=+17.6 \%)$ and haptoglobin. However, the higher values noted in nonthe specialists were noted for RBC and PLT.

During the recovery period (Table 4), the two-factor Anova shows the evolution of haematological parameters: a significant "group" effect $[\mathrm{F}(1.74)=15.73$; $\mathrm{p}=0.001]$; as well as a significant "group $\times$ recovery" interaction $[\mathrm{F}(3.72)=$ 8.31; $\mathrm{p}<0.01]$. One-way analysis of variance (recovery) in the non-specialist endurance race group shows a significant effect $[\mathrm{F}(4.33)=4.8 ; \mathrm{p}<0.01]$, the same for the group of specialists $[\mathrm{F}(4.35)=3.17 ; \mathrm{p}<0.05]$. The post hoc Schoffe's test shows that RBC, PLT, RDW, neutrophil counts, lymphocyte counts and MPV decreased without reaching basal values throughout the sample The rates of decrease between the end of the effort and the 24 hours of recovery were respectively: $-8.3 \%(\mathrm{p}<0.05),-20.9 \%(\mathrm{p}<0.001),-3.9 \%(\mathrm{p}>0,05),-40 \%$ $(\mathrm{p}<0.001),-4.3 \%(\mathrm{p}>0.05)$ and $-4 \%(\mathrm{p}>0,05)$. However, an increase in values was noted for MCH and MCHC: $+5.1 \%(\mathrm{p}<0.05)$ and $+4.3 \%(\mathrm{p}>0.05)$. The decline observed for $\mathrm{Hb}$ was not significant. 
Table 3. Mean values $( \pm S D)$ of red cells, leukocytes and platelet parameters and serum haptoglobin levels before and after race for specialists and no specialists of endurance course.

\begin{tabular}{|c|c|c|c|c|}
\hline & \multicolumn{2}{|c|}{ Before } & \multicolumn{2}{|c|}{ After } \\
\hline & $\begin{array}{l}\text { Specialists } \\
(\mathrm{n}=39)\end{array}$ & $\begin{array}{l}\text { No specialists } \\
\quad(\mathrm{n}=37)\end{array}$ & $\begin{array}{l}\text { Specialists } \\
(\mathrm{n}=39)\end{array}$ & $\begin{array}{l}\text { No specialists } \\
\quad(\mathrm{n}=37)\end{array}$ \\
\hline $\mathrm{RBC}\left(\times 10^{16} / \mu \mathrm{L}\right)$ & $4.9 \pm 0.3^{\star *}$ & $4.5 \pm 1.0$ & $5.1 \pm 0.5$ & $5.0 \pm 0.4^{\star}$ \\
\hline $\mathrm{Hb}(\mathrm{g} / \mathrm{dL})$ & $14.8 \pm 0.2^{* *}$ & $13.2 \pm 0.5$ & $15.4 \pm 0.3$ & $15.0 \pm 0.2$ \\
\hline Hct (\%) & $42.9 \pm 0.1$ & $43.5 \pm 0.3^{*}$ & $45.7 \pm 0.4$ & $45.1 \pm 0.8$ \\
\hline $\operatorname{PLT}\left(\times 10^{13} / \mu \mathrm{L}\right)$ & $244 \pm 11$ & $234 \pm 15$ & $315 \pm 13$ & $307 \pm 10^{*}$ \\
\hline$\Delta \mathrm{VP}(\%)$ & -- & -- & $15.1 \pm 0.9^{*}$ & $14.3 \pm 1.1$ \\
\hline MCV (fL) & $89.6 \pm 0.5$ & $88.8 \pm 0.7$ & $94.2 \pm 0.8$ & $93.4 \pm 10.1$ \\
\hline $\mathrm{MCH}(\mathrm{pg})$ & $30.6 \pm 0.3$ & $30.4 \pm 0.5$ & $30.8 \pm 0.7$ & $28.4 \pm 10.3$ \\
\hline $\mathrm{MCHC}(\mathrm{g} / \mathrm{dL})$ & $30.4 \pm 0.5$ & $32.0 \pm 0.1^{\star}$ & $32.5 \pm 6.0$ & $32.3 \pm 0.8$ \\
\hline RDW (\%) & $13.1 \pm 0.1^{\star}$ & $12.5 \pm 0.3$ & $13.7 \pm 0.2^{\star}$ & $12.9 \pm 0.1$ \\
\hline $\mathrm{WBC}(/ \mu \mathrm{L})$ & $7401 \pm 102$ & $6425 \pm 96$ & $6745 \pm 125$ & $6739 \pm 62$ \\
\hline Neutr. $(/ \mu \mathrm{L})$ & $3752 \pm 31$ & $3728 \pm 20$ & $5269 \pm 128$ & $5057 \pm 114$ \\
\hline Lymph. $(/ \mu \mathrm{L})$ & $2112 \pm 17$ & $2106 \pm 22$ & $2220 \pm 61$ & $2210 \pm 68$ \\
\hline Mono. $(/ \mu \mathrm{L})$ & $625 \pm 8^{*}$ & $593 \pm 14$ & $716 \pm 15$ & $710 \pm 21$ \\
\hline Eosino. $(/ \mu \mathrm{L})$ & $184 \pm 12^{*}$ & $168 \pm 9$ & $178 \pm 14$ & $172 \pm 17$ \\
\hline Baso. $(/ \mu \mathrm{L})$ & $50 \pm 5$ & $48 \pm 16$ & $58 \pm 9^{*}$ & $44 \pm 6$ \\
\hline MPV (fL) & $7.9 \pm 0.3$ & $8.7 \pm 0.2^{*}$ & $9.1 \pm 0.1^{*}$ & $7.5 \pm 0.3$ \\
\hline Haptoglobin (g/L) & $1.25 \pm 1.30^{*}$ & $1.03 \pm 0.51$ & $0.98 \pm 0.23^{\star}$ & $0.94 \pm 0.18$ \\
\hline
\end{tabular}

${ }^{* *}: \mathrm{p}<0.01 ; * \mathrm{p}<0.05$

Table 4. Mean values $( \pm \mathrm{SD})$ of red cells, leukocytes and platelets in post-race and during recovery for 27 subjects.

\begin{tabular}{ccccc}
\hline & After & $+3 \mathbf{h}$ & $+6 \mathbf{h}$ & $+24 \mathbf{h}$ \\
\hline $\mathrm{RBC}\left(\times 10^{16} / \mu \mathrm{L}\right)$ & $5.2 \pm 0.1$ & $5.1 \pm 0.3$ & $4.9 \pm 0.1$ & $4.8 \pm 0.2$ \\
$\mathrm{Hb}(\mathrm{g} / \mathrm{dL})$ & $15.2 \pm 0.1$ & $15.1 \pm 0.7$ & $15.0 \pm 0.2$ & $14.9 \pm 0.4$ \\
$\mathrm{PLT}\left(\times 10^{13} / \mu \mathrm{L}\right)$ & $311 \pm 26$ & $292 \pm 25$ & $307 \pm 41$ & $246 \pm 18$ \\
$\mathrm{MCV}(\mathrm{fL})$ & $93.8 \pm 0.9$ & $92.4 \pm 0.6$ & $90.3 \pm 1.4$ & $88.0 \pm 0.7$ \\
$\mathrm{MCH}(\mathrm{pg})$ & $29.6 \pm 0.5$ & $30.0 \pm 0.3$ & $30.5 \pm 1.2$ & $31.1 \pm 0.2$ \\
$\mathrm{MCHC}(\mathrm{g} / \mathrm{dl})$ & $32.4 \pm 0.8$ & $32.9 \pm 0.5$ & $33.1 \pm 0.8$ & $33.8 \pm 0.4$ \\
$\mathrm{RDW}(\%)$ & $13.3 \pm 0.4$ & $13.1 \pm 0.6$ & $12.9 \pm 0.3$ & $12.8 \pm 0.05$ \\
WBC $(/ \mu \mathrm{L})$ & $6713 \pm 131$ & $6685 \pm 53$ & $6504 \pm 71$ & $6473 \pm 42$ \\
Neutr. $(/ \mu \mathrm{L})$ & $5263 \pm 123$ & $5126 \pm 32$ & $4328 \pm 40$ & $3816 \pm 25$ \\
Lymphocyte $(/ \mu \mathrm{L})$ & $2215 \pm 66$ & $2097 \pm 50$ & $2173 \pm 38$ & $2124 \pm 20$ \\
Mono. $(/ \mu \mathrm{L})$ & $713 \pm 48$ & $720 \pm 13$ & $622 \pm 15$ & $613 \pm 34$ \\
MPV $(\mathrm{fL})$ & $8.8 \pm 0.4$ & $8.7 \pm 0.6$ & $8.6 \pm 0.3$ & $8.3 \pm 0.5$ \\
\hline
\end{tabular}




\section{Discussion}

The present study aimed to evaluate hematological changes in Congolese half-marathon runners at the end of this test and during the next 24 hours. Compared with European haematological standards [12] [13] and those described elsewhere in Africa [14]-[22], our mean values are lower, more compared to Caucasian data [13]. However, the interpretation of our results must take into account certain limitations. The first is the average mode of expression, most likely influenced by the small size of the sample. The second is the method of collecting information on morbid antecedents and lifestyle: these relied only on the declarations of the participations, without rigorous verification. In addition, it would be wise to evaluate the loss of iron from serum ferritin following the great sweating noted by the runners because of the strong heat recorded that morning in Brazzaville. Finally, the usual factors of confusion such as age and altitude, were not taken into account. However, these evoked limits do not completely affect the power of the observations. This study is in all cases, the first in our black African environment, including healthy individuals. This study provides a useful data base for athlete tracking, although the inclusion of more subjects is essential.

Our data show that endurance athletes (specialists) tend to have lower hematocrit and hemoglobin values than no specialists. This observation created a wealth of conflicted evidence regarding possible mechanisms and whether these changes constitute a real pathology entity various termed "athletes", "runners", or "sports anemia". A review [23] provides an up-to-data and comprehensive critique of the main hypotheses and relevant literature. This review concludes that the changes may be regarded as a physiologic response by the homeostatic mechanisms controlling hemoglobin concentration to an unphysiologically intense and prolonged exercise load. The central principle to this concept in the dilutional effect resulting from an increase in plasma volume exceeding that involving the red cell mass. The favored mechanism is therefore analogous to that which accounts for the physiologic "anemia" of pregnancy [24]. However, we could emphasize that many subsidiary factors, acting alone or in combination, may modify the overall dilution effect by influencing either or both plasma volume and red cell mass.

Thus, plasma volume may vary in the short term according to the time of blood sampling in relation to different patterns (type, intensity, and duration) of exercise. Under standard environmental conditions, the hematocrit in trained male athletes is minimally increased on completion of a half-marathon [25]; but our study demonstrates a progressive fall during the subsequent $24 \mathrm{~h}$ representing a $9.3 \% \pm 5.2 \%$ increase in the baseline plasma volume. This dilutional phenomenon has been observed previously [26] [27] and its possible explanation based on the exercise-induced increase in renin-aldosterone secretion [28]. Continuing severe exercise in the form of cross-country [29], combat training [30], and endurance road running [5] has been reported to induce fall 
in hematocrit during the first few days of the activity. This reduced hematocrit is then sustained for $2-3$ days following cessation of the activity before returning it the pre-exercise level.

Many factors may also modify, particularly impair, the increase in red cell mass which develops in well-trained distance runners [31]. In the main, most hinge or loss or secondary deficiency to mechanisms directly with running itself, but in individual athletes blood loss occasionally results from disease unrelated to but which may be aggravated by running.

In additional, of greater interest, however, is our second observation that in $30 \%$ of our runners $(n=23)$ shower a significant decrease in hematocrit. These unusual and variable plasma volume responses require elucidation and are the subjects of our ongoing studies.

In this study, leukocyte values increased with physical effort and decreased during $+24 \mathrm{~h}$. Leukocytosis following physical stress is a well and long recognized phenomenon and has been reported to follow short-term and endurance forms of exercise. Administration of adrenaline and corticosteroids [32] [33] has been shown to promote similar changes in leukocyte numbers, and it has now been established that the magnitude of granulocytosis (neutrophils and monocytes) following a 20-mile run is not only stress-dependent but also positively correlated with serum cortisol and inversely correlated with prior training [34]. A cortisol-mediated fall in eosinophil is also expected and indeed is the basis of a test of adrenocortical function [35]. Finally, in relation to the granulocyte response to prolonged exercise, our results clearly indicate that $15.5 \%$ of runners $(n=12)$ with mild pre-race leukopenia all demonstrated a normal or even greater than normal reactive leukocytosis following the race. These findings not only suggest such subjects may have a decreased circulating granulocyte pool due to increased margination and sequestration but also substantiate the view [36] that exercise elicits a normal granulocyte demargination and mobilization response in subjects with "shift-neutropenias".

On another side, exercise also induces significant lymphocytosis [37], as we have observed in this study. This one is mainly due to increase in non-T cells [38] probably mobilized from the spleen [39]. Studies making use of monoclonal antibodies specific for lymphocyte surface antigens showed that these cells our characterized as natural killer (NK) cells (Leu 7 and 11). As the administration of cortico-steroids usually causes lymphopenia, the mechanism of post-exercise lymphocyosis is thought to be unrelated to adrenalin release [40] and to be independent of cortisol levels [41].

Our findings also indicated that half-marathon was associated a 16\% (range: $12 \%-25 \%)$ increase in the venous platelet count, which normalized to the pre-race level with $3 \mathrm{~h}$ of completion of the run. This augmentation was not accompanied by a significant change in MPV. Finally, our observations are consistent with those of Massimo and al [42]. According to these authors, the spleen is the major platelet-releasing organ, but the coexistence of an intravascular marginal pool particularly within pulmonary circulation is likely. 


\section{Conclusion}

The results of this study show that the haematological changes associated with the half-marathon race in the African tropics as elsewhere, are very specific to this type of effort. Some runners present at rest abnormal Hb, Hct, platelet count and $\mathrm{Hp}$ values. The recorded data suggest that a half-marathon race practiced in the hot and wet environment of the Congo causes fluid losses, a decreased circulating granulocyte pool and a significant increase in the immediate post-race MCV due by the hyperosmolar plasma environment associated with semi-marathon. The fact that during the 24 hours following the test the basic hematological values are not reached in the majority of cases, suggests that a priori it should review the mode of rehydration during the test, especially the nature of stress drinks. This should allow eventually overcoming the consequences, in terms of heart fatigue, neuromuscular or gastrointestinal disorders.

\section{Acknowledgements}

The authors would like to acknowledge haematology laboratory staff of Pasteur Institute who contributed to data collection. We are grateful to all volunteers who made by their consent the study possible. Warms thanks to Professor Dr TJJ Muyembe of the National Institute for Biomedical Research of Kinshasa (D.R. Congo) for all faculties obtained to carry out the present study. This research was supported by a grant from Organization for Scientific Co-operation and Development (grant NL-4397).

\section{Footnote}

MJGA conceived and conducted the study, participated in statistical analyses and wrote the manuscript. MELS and MJM participated in the study design and data acquisition. NMC and PMD participated in data acquisition. NOJ, PLC and PTB conducted statistical analyses and revised the manuscript. MA wrote the study protocol and revised the manuscript.

\section{Conflicts of Interest}

The authors declare no conflicts of interest regarding the publication of this paper.

\section{References}

[1] Millet, G.Y. and Lepers, R. (2004) Alterations of Neuromuscular Function after Prolonged Running, Cycling and Skiing Exercises. Sports Medicine, 34, 105-116. https://doi.org/10.2165/00007256-200434020-00004

[2] Cuesta, T.M. and Singer, M. (2012) The Stress Response and Critical Illness: A Review. Critical Care, 40, 3283-3289. https://doi.org/10.1097/CCM.0b013e31826567eb

[3] Hoffman, M.D., Pasternak, A., Rogers, I.R., Khodace, M., Hill, J.C., Townes, D.A., et al. (2014) Medical Service at Ultra-Endurance Foot Races in Remote Environments: Medical Issues and Consensus Guidelines. Sports Medicine, 44, 1055-1069. https://doi.org/10.1007/s40279-014-0189-3 
[4] FCA (2018) Etude Semi-Marathon International de Brazzaville. Naissance évolution et perspectives. Rapport d'une commission d'experts africains en athlétisme. Fédération Congolaise d'Athlétisme, Brazzaville, $52 \mathrm{p}$.

[5] Dressendorfer, R.H., Wade, C.E. and Amsterdam, E.A. (1981) Development of Pseudoanemia in Marathon Runners during a 20-Day Road Race. Journal of the American Medical Association, 246, 1215-1218. https://doi.org/10.1001/jama.1981.03320110027020

[6] Davidson, R.J.L., Robertson, J.D., Galea, G. and Maughan, R.J. (1987) Hematological Changes Associated with Marathon Running. International Journal of Sports Medicine, 8, 19-25. https://doi.org/10.1055/s-2008-1025634

[7] Whiting, P.H., Maughan, R.J. and Miller, J.D.B. (1984) Dehydratation and Serum Biochemical Changes in Marathon Runners. European Journal of Applied Physiology, 52, 183-1987. https://doi.org/10.1007/BF00433390

[8] Lord, R., George, K., Somauro, J., Stembridge, M., Jain, N., Hoffman, M.D., et al. (2016) Alteration in Cardiac Mechanics Following Ultra-Endurance Exercise: Insights from Left and Right Ventricular Area-Deformation Loops. Journal of the American Society of Echocardiography, 29, 871-879. https://doi.org/10.1016/j.echo.2016.05.004

[9] Balducci, P., Clemencon, M., Morel, B., Quiniou, G., Saboul, D. and Hautier, C.A. (2016) Comparison of Level and Graded Tradmill Tests to Evaluate Endurance Mountains Runners. Journal of Sports Science \& Medicine, 15, 239-246.

[10] Van Beaumont, W. (1972) Evaluation of Hemoconcentration from Hematocrit Measurements. Journal of Applied Physiology, 31, 712-713. https://doi.org/10.1152/jappl.1972.32.5.712

[11] Sokal, R.F. and Rolf, S.W. (1995) Biometry. 7th Edition, Freeman and Co., San Francisco.

[12] Troussard, X., Vol, S., Cornet, E., Bardet, V., Couillac, J.P., et al. (2014) Full Blood Count Normal Reference Values for Adults in France. Journal of Clinical Pathology, 67, 341-344. https://doi.org/10.1136/jclinpath-2013-201687

[13] Katayev, C., Baleiza, P. and Secombe, D.W. (2010) Establishing Reference Intervals for Clinical Laboratory Test Results: Is There a Better Way? American Journal of Clinical Pathology, 133, 180-186. https://doi.org/10.1309/AJCPN5BMTSF1CDYP

[14] Kone, B., Maiga, M., Baya, B., Sarro, Y.D.S., Coulibaly, N., Kone, A., et al. (2017) Establishing Reference Ranges of Hematological Parameters from Malian Healthy Adults. Journal of Blood and Lymph, 7, 154.

[15] Adetifa, I.M., Hill, P.C., Jeffries, D.J., Jackson-Sillah, D., Ibanga, H.B., et al. (2009) Haematological Values from a Gambian Cohort-Possible Reference Range for a West African Population. International Journal of Laboratory Hematology, 31, 615-622. https://doi.org/10.1111/j.1751-553X.2008.01087.x

[16] Lugada, E.S., Mermin, J., Kaharuza, F., Ulvestad, E., Were, W., et al. (2004) Population-Based Hematologic and Immunologic Reference Values for a Healthy Uganda Population. Clinical and Diagnostic Laboratory Immunology, 11, 29-34. https://doi.org/10.1128/CDLI.11.1.29-34.2004

[17] Böhler, T., Kynast-Wolf, G., Coulibaly, B., Siec, A. and Kapunb, A. (2008) Gender-Specific Distribution of Hematological Parameters in Adults Living in Nouna, Burkina-Faso. The Open Hematology Journal, 2, 1-4. https://doi.org/10.2174/1874276900802010001

[18] Kueviakoe, I.M., Segbena, A.Y., Jouault, H., Vovor, A., Imbert, M., et al. (2010) Hematological Reference Values for Healthy Adults in Togo. International Scholar- 
ly Research Notices, 2011, e736062. https://doi.org/10.5402/2011/736062

[19] Miri-Dashe, T., Osawe, S., Tokdung, M., Daniel, N., Choji, R.P., et al. (2014) Comprehensive Reference Ranges for Hematology and Clinical Chemistry Laboratory Parameters Derived from Normal Nigerian Adults. PLoS ONE, 9, e93919. https://doi.org/10.1371/journal.pone.0093919

[20] Tsegaye, A., Messele, T., Tilahum, T., Hailu, E., Sahlu, T., et al. (1999) Immunohematological Reference Ranges for Adults Ethiopians. Clinical and Diagnostic Laboratory Immunology, 6, 410-414.

[21] Tembe, N., Joaquim, O., Alfai, E., Sitoe, N., Viegas, E., et al. (2014) Reference Values for Clinical Laboratory Parameters in Young Adults in Maputo, Mozambique. PLoS ONE, 9, e97391. https://doi.org/10.1371/journal.pone.0097391

[22] Al-Sweedan, S.A. and Alhaj, M. (2012) The Effect of Low Altitude on Blood Count Parameters. Hematology/ Oncology and Stem Cell Therapy, 5, 158-161. https://doi.org/10.5144/1658-3876.2012.158

[23] Halberg, L. and Magnusson, B. (1984) The Aetiology of "Sports Anemia". Acta Medica Scandinavica, 216, 145-148. https://doi.org/10.1111/j.0954-6820.1984.tb03785.x

[24] Hytter, F.E. and Paintin, D.B. (1963) Increase in Plasma Volume during Normal Pregnancy. Journal of Obstetrics and Gynaecology of the British Commonwe, 73, 181-190.

[25] Selby, G.B. and Eichner, E.R. (1994) Hematocrit and Performance: The Effect of Endurance Training on Blood Volume. Seminars of Hematology, 31, 122-127.

[26] Convertino, V.A. (1991) Blood Volume: Its Adaptation to Endurance Training. Medicine \& Science in Sports \& Exercise, 23, 1338-1348. https://doi.org/10.1249/00005768-199112000-00004

[27] Greenleaf, J.E., Convertino, V.A. and Mangseth, G.R. (1979) Plasma Volume during Stress: Osmolality and Red Cell Volume. Journal of Applied Physiology, 47, 1031-1038. https://doi.org/10.1152/jappl.1979.47.5.1031

[28] Geyssant, A., Geelen, G., Denis, C., Allevard, A.M., Vincent, M., Jarsaillon, E., et al. (1981) Plasma Vasopressin, Renin Activity, and Aldosterone: Effect of Exercise and Training. European Journal of Applied Physiology, 46, 21-30. https://doi.org/10.1007/BF00422171

[29] Astrand, P.O. and Saltin, B. (1964) Plasma and Red Cell Volume after Prolonged Severe Exercise. Journal of Applied Physiology, 19, 829-832. https://doi.org/10.1152/jappl.1964.19.5.829

[30] Lindeman, R., Ekanger, R., Opstad, P.K., Nummestad, M. and Ligosland, P. (1978) Haematological Changes in Normal Men during Prolonged Severe Exercise. American Corrective Therapy Journal, 32, 107-111.

[31] Brotherhood, J., Brozovic, B. and Pugh, L.G.C. (1975) Haematological Status of Middle- and Long-Distance Runners. Clinical Science and Molecular Medicine, 48, 139-145. https://doi.org/10.1042/cs0480139

[32] Bishop, C.R., Athens, G.W., Boggs, D.R. and Warner, H.R. (1968) A Non-Steady-State Kinetic Evaluation of the Mechanism of Cortisone Induced Granulocytosis. Journal of Clinical Investigation, 47, 249-260. https://doi.org/10.1172/JCI105721

[33] Fauci, A.S. and Dale, D.C. (1974) The Effect of in Vivo Hydrocortisone on Subpopulations of Human Lymphocytes. Journal of Clinical Investigation, 53, 240-246. https://doi.org/10.1172/JCI107544

[34] Thorns, G.W., Forsham, P.H., Prunty, F.T.G. and Hills, A.G. (1948) Test for Adrenal Cortisol Insufficiency. JAMA, 137, 1005-1009. 
https://doi.org/10.1001/jama.1948.02890510044016

[35] Bishop, C.R., Rothstein, G., Ashenbrukler, H.E. and Athens, J.W. (1971) Blood Neutrophil Kinetics in Chronic, Steady-State Neutropenia. Journal of Clinical Investigation, 50, 1678-1689. https://doi.org/10.1172/JCI106657

[36] Garrey, W.E. and Bryan, W.R. (1935) Variations in White Blood Cell Counts. Physiological Reviews, 15, 597-638. https://doi.org/10.1152/physrev.1935.15.4.597

[37] Steel, C.M., Evans, J. and Smith, M.A. (1974) Physiological Variation in Circulating B Cell: T Cell Ratio in Man. Nature, 247, 387-388. https://doi.org/10.1038/247387a0

[38] Hedfors, E., Biberfeld, P. and Wahren, J. (1978) Mobilisation to the Blood in Human Non-T and K Lymphocytes during Physical Exercise. Journal of Clinical and Laboratory Immunology, 1, 159-162.

[39] Frier, B.M., Cornall, R.J.M., Davidson, N.McD., Webber, R.G., Dewar, A. and French, E.B. (1983) Peripheral Blood Cell Changes in Response to Acute Hypoglycaemia in Man. European Journal of Clinical Investigation, 13, 33-39. https://doi.org/10.1111/j.1365-2362.1983.tb00061.x

[40] Malm, C., Sjodin, T.L., Sjoberg, B., Lenkei, R., Renstrom, P., Lundberg, I.E., et al. (2004) Leukocytes, Cytokines, Growth Factors and Hormones in Human Skeletal Muscle and Blood after Uphill or Downhill Running. The Journal of Physiology, 556, 983-1000. https://doi.org/10.1113/jphysiol.2003.056598

[41] Dawson, A.A. and Ogston, D. (1969) Exercise-Induced Thrombocytosis. Acta Haematologica, 42, 241-246. https://doi.org/10.1159/000208784

[42] Di Massimo, C., Scarpelli, P. and Tozzi-Gancarelli, M.G. (2004) Possible Involvement of Oxidative Stress in Exercise-Mediated Platelet Activation. Clinical Hemorheology and Microcirculation, 30, 313-316. 


\section{Individual Information Sheet}

\section{Social and Clinical Characteristics}

Name (s):

First name (s):

Age (years):

Sex:

Nationality:

Nationality of the father:

Nationality of the mother:

Place of residence:

A number of years of residence:

Family status:

Profession:

Medical antecedents:

\section{Specificities of the Sporting Practice}

Practised sport:

Speciality:

A number of years of practice of the race of endurance:

Level of practice:

Professional

Semi-professional

Amateur

A number of participations in the Brazzaville International Half-Marathon:

Better row occupied at the time of the participation:

Year: 